\title{
COMMENT ON PROFESSOR SCHWENZER'S PAPER
}

\author{
Nicholas Whittington*
}

\section{INTRODUCTION}

This short paper expands on my response at the symposium to Professor Schwenzer's discussion of the application by domestic courts of the CISG in the particular case of the determination of fundamental breach.

Professor Schwenzer discussed the single standard concept of fundamental breach as being the decisive factor in the continuing existence of a contract. Fundamental breach involves a case-bycase categorisation of the severity of the breach as a prerequisite to avoidance, and therefore, she argued, is the crucial component in making the system of remedies for breach of contracts under the CISG effective and cohesive.

Professor Schwenzer's paper was itself a reaction to the criticism of the central role of this single standard concept. Those who continue to denounce the CISG approach to avoidance have missed the point of the CISG. The CISG is a simple document, written in plain business language. ${ }^{1}$ This is necessarily the case because it is to be applied by courts and arbitrators across the globe and in a wide variety of sale situations. Given the CISG's aim, a document weaving together the practicalities of international trade and a complex structure of rules for different contracts simply would not work at the point of application by decision-makers. It is vital that such an ambitious and broad document is open-textured and gives enough room to decision-makers to make it workable. A single standard concept is the best way to achieve this.

It is the application of the CISG by decision-makers that I wish to discuss in this paper. For my part, the greatest threat to single standard concepts such as fundamental breach being effectively applied is not the content of the rule itself. Instead, there appear to be two fundamental problems in achieving uniform application of the CISG. The first is a reluctance of courts to review foreign case law to assist in decision-making, which has resulted in an unfortunate amount of contradictory jurisprudence. The second is the inability of decision-makers to distance themselves from domestic

* BA, LLB(Hons), Judges Clerk, Court of Appeal.

1 This is essentially the point also of Professor Schlechtriem's paper. 
preconceptions of interpretation. I will discuss these two issues before tentatively proposing ways of overcoming the resulting difficulties.

\section{REVIEW OF FOREIGN CASE LAW}

The now considerable case law on the CISG demonstrates that the application of many of these single standard concepts has been far from uniform. ${ }^{2}$

One particular provision with which domestic courts have had problems is Article 35 which requires that the goods delivered conform to the contract description, or be fit for ordinary purposes. A particular and frequent issue with cross-border trade, and this Article in particular, is whether the goods must conform to the public or administrative law regulations in the buyer's country when the contract does not expressly deal with the issue.

On this point there is contradictory jurisprudence. For example, in the well-known New Zealand Mussels case, a Swiss company sold New Zealand mussels to a German buyer. The mussels were not fit for consumption in Germany since the levels of cadmium found in the mussels were higher than German public health regulations permitted. The Bundesgerichtshof (German Supreme Court) ${ }^{3}$ held that the seller is not required to ensure that goods sold pass public health regulations unless the seller has special knowledge of the provisions.

However in a later case, the Cour d'appel (Court of Appeal) of Grenoble held that the seller is bound to ensure that the product will satisfy any applicable sales regulations in the buyer's country. ${ }^{4}$ In that case, a French buyer of Italian cheese was unable to retail the cheese because it did not satisfy French cheese packaging laws.

The same two courts have also disagreed on the question of the burden of proof for a lack of conformity in the goods delivered. The German court has held that the buyer ordinarily has the burden of proving the lack of conformity, ${ }^{5}$ whereas the Cour d'appel of Grenoble has held that the seller does. ${ }^{6}$

2 See the helpful analysis of Larry DiMatteo, Lucien Dhooge, Stephanie Greene, Virginia Maurer and Marisa Pagnattaro "The Interpretive Turn in International Sales Law: An Analysis of 15 Years of CISG Jurisprudence" (2004) 34 Northwestern Journal of International Law and Business 299.

3 Bundesgerichtshof (German Supreme Court), 8 March 1995, VIII ZR 159/94 <www.cisg-online.ch> (last accessed 6 November 2005).

4 Cour d'appel Grenoble, 13 September 1995, 93/4126, <http://www.cisg.law.pace.edu> (last accessed 6 November 2005).

5 Bundesgerichtsof 9 May 2002, VIII ZR 304/00, <http://www.cisg.law.pace.edu > (last accessed 6 November 2005). However, on the "special circumstances of the case" the Court found that the seller had the burden of proof.

6 Cour d'appel Grenoble, 15 May 1996, 94/0258, <http://www.cisg.law.pace.edu> (last accessed 6 November 2005). 


\section{DOMESTIC PRECONCEPTIONS OR HOMEWARD TREND}

The lack of uniformity is not caused only by case law which fails to have regard to decisionmaking in other jurisdictions. It is also caused by national courts that ignore autonomous and CISGcompliant interpretations in favour of interpretations in line with their domestic law, a phenomenon sometimes called "homeward trend". The drafters of the CISG, mindful that this might occur, wrote in the Secretariat Commentary to Article 7, "it is especially important to avoid differing constructions of the provisions of this Convention by national courts, each dependent upon the concepts used in the legal system of the country of the forum."7 This warning has not been well heeded.

A striking example of homeward trend is an Italian case where the Corte di Appello (Court of Appeal) of Milan held that late delivery was a fundamental breach entitling avoidance of the contract under Article 49 without undertaking the examination required by the CISG of whether the late delivery amounted to a fundamental breach under Article 25. ${ }^{8}$ The Court used the Italian conception of fundamental breach rather than the CISG's autonomous meaning to bypass this essential step.

Furthermore, in relations to Articles 38 and 39 which regulate the examination of delivered goods and the giving of notices of defects, the CISG Advisory Council reports that: ${ }^{9}$

While many of the decisions that have been reported to date are unobjectionable on their facts, there has

been a tendency on the part of some courts to interpret CISG articles 38 and 39 in the light of the analogous provisions in their domestic law.

According to a recent article, ${ }^{10}$ this appears to be the case right across the board.

It will not be easy for a court to shed its domestic perspective and look at the case before it with unfamiliar eyes, "no longer influenced by the law of its own nation state."11 However, that courts do so is critical to the CISG's goal of uniformity.

7 Explanatory Note by the UNCITRAL Secretariat on the United Nations Convention on Contracts for the International Sale of Goods, Art 7 Pace Law School CISG Database < http://www.cisg.law.pace.edu $>$ (last accessed 6 November 2005).

8 Corte di Appello Milan, 20 March 1998, <http://www.cisg.law.pace.edu> (last accessed 6 November 2005).

9 CISG-AC Opinion No 2, Examination of the Goods and Notice of Non-Conformity: Articles 38 and 39,7 June 2004, para 5.2, <http://www.cisg.law.pace.edu> (last accessed 6 November 2005).

10 See Larry DiMatteo, Lucien Dhooge, Stephanie Greene, Virginia Maurer and Marisa Pagnattaro "The Interpretive Turn in International Sales Law: An Analysis of 15 Years of CISG Jurisprudence” (2004) 34 Northwestern Journal of International Law and Business 299.

11 John Murray "The Neglect of the CISG: A Workable Solution" (1998) 17 Journal of Law and Commerce 365,367 . 


\section{SOLUTIONS}

So how are we to promote the harmonisation of jurisprudence in relation to the CISG? As will be clear from what is said above, the first step to harmonisation is to encourage decision-makers to have regard to case law from other countries in decision-making. This is one of the points made by Professor Schlechtriem in the context of his discussion of Article 7. It is imperative that courts look to foreign decisions for guidance. With the recent growth of online CISG databases we are beginning to see progress in this area.

In this regard it is important that higher courts lead by example, making binding precedents in common law countries, and making landmark decisions in civil law countries. I note here, as an example of what not to do, that the Cour de Cassation (Supreme Court of France) has recently decided that the determination of reasonable time, a notion littered throughout the CISG, should be left solely to lower court judges. ${ }^{12}$ This decision is unfortunate. In doing so, France's highest civil court has effectively refused to make a contribution in this area, one of the most delicate in the CISG. The decision also has the potential to lead to divergent interpretations within France. Where there is a real possibility for divergence within a jurisdiction, what chance is there for consistency between jurisdictions?

However, while a consideration of CISG jurisprudence from other jurisdictions will undoubtedly aid the harmonisation process, we must be aware of the practical difficulties in doing so. In addition to the obvious language difficulties involved, decision-makers must be aware of, and understand, different legal attitudes. Common lawyers are frequently exasperated by reading, for example, French court decisions, which are seemingly given without explanation for the decision (that is, in comparison with the reasons attached to common law decisions). Readers should be aware that in civil countries the reasons for a decision do not play the same role that they do in a common law system. An average Cour de Cassation decision is half a page long, and frequently decisions seem unmotivated. It is simply what the French call "la méthode devinatoire", and is the result of case reporting practice in France rather than an indication that the decision is not fully reasoned. My point is that domestic practices such as this, and unawareness of them, can be a hindrance to understanding other jurisdictions, and therefore, to harmonising CISG jurisprudence.

The second step is to encourage courts, when dealing with the CISG, to distance themselves from domestic preconceptions, and to look at the case through CISG-tinted glasses. A fear of the unknown is understandable, but not an excuse for not applying the clear words of the Convention when necessary. A good example of such a domestic preconception is Article 7's requirement of good faith. There appears to be a fear (in common law countries such as the UK or New Zealand) that such a requirement will limit a party's contractual freedom, or that it will give judges too much

12 Cour de Cassation 26 May 1999, P 97-14.315 Arrêt 994 D <http://www.cisg.law.pace.edu> (last accessed 6 November 2005). 
scope to create law. However, the autonomous interpretation of Article 7 Professor Schlechtriem proposed would not have such an effect. It is worthwhile to note that other legal systems do not encounter these problems. Good faith has been an integral part of contract law in France for over 200 years and it seems to work well enough. That it does not pervade English contract law, nor that of related legal systems, is not a reason to fail to apply it.

\section{CONCLUSION}

The greatest threat to a uniform sales law is not the substance of the sales law but a less than strict adherence to the interpretive principles within it. The CISG is a necessarily open-textured document with the result that it relies heavily on the ability of decision-makers to apply it with uniformity. A single standard concept such as fundamental breach in Article 25 is the most practical and effective way of realising uniformity. However, if courts applying the CISG continue to fail to have regard to case law from other jurisdictions, and continue to depend upon domestic interpretations, the goal of uniform application remains some way off. 
